\title{
LEGAL INFORMATION MANAGEMENT
}

Journal of the British and Irish Association of Law Librarians 


\section{Legal Information Management}

Journal of the British and Irish Association of Law Librarians

\section{Contents}

Editorial

David Wills

\section{OCCASIONAL SERIES}

Conversations with Michael J. Prichard: the Fun of Legal History and the Triumph of Research Over Administration Lesley Dingle

The BIALL Law Firm Library Survey 2019/2020

\section{CURRENT INTERESTS}

Artificial Intelligence and Race: a Systematic Review

\section{FOCUS ON LEGAL PUBLISHERS AND SUPPLIERS}

Bailey Solutions. Responding to Change: Surviving the Financial Crisis, the Pandemic and Everything Else!

Penny Bailey

vLex Justis: the Alternative Just Got Better

Masoud Gerami and Aidan Hawes

\section{SHORTER ARTICLES}

The Justis International Law \& Technology Writing Competition 2020

Matthew Terrell and David Hand

Machine-Learnt Bias? Algorithmic Decision Making and Access to Criminal Justice

Malwina Anna Wojcik

Let Justice be Done Though the Overheads Fall: How Online Courts Promote Access to Justice

Armin Amirsolimani

The 'Personal' in Personal Data: Who is Responsible for Our Data and How Do We Get it Back? Janis Wong

502 Bad Gateway: Rebooting Smart Contracts

Alicia Lim

\section{INTERNATIONAL PERSPECTIVES}

Collection Development of Legal Information Resources in the Supreme Court of India 


\title{
Legal Information Management \\ Published on behalf of the British and Irish Association of Law Librarians www.biall.org.uk
}

\author{
Editor \\ David Wills, B.A. (Hons) M.A.(Cantab) Dip.Lib. MCLIP \\ Squire Law Library, 10 West Road, Cambridge, CB3 9DZ \\ Tel: 0122333007 I \\ Email: dfw1003@cam.ac.uk

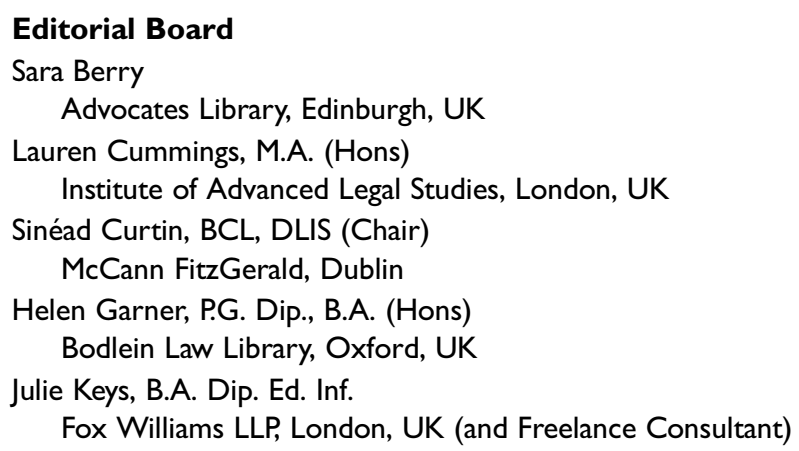

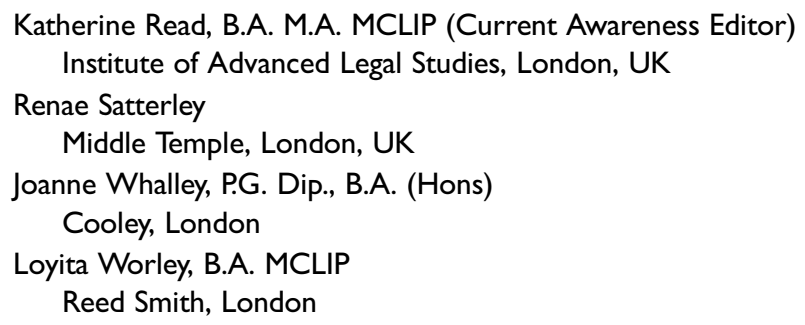

Legal Information Management is the official journal of the British and Irish Association of Law Librarians. Aimed at professionals active in the legal information community this topical journal provides invaluable information for all those involved in the provision of legal information in the academic and professional environments. Published quarterly, and with an extensive current awareness section, a regular internationally focused article and coverage of management issues, Legal Information Management is the international journal for legal information professionals everywhere.

\section{Subscriptions}

Legal Information Management (ISSN 1472-6696) is published quarterly in March, June, September and December. Four parts form a volume. The subscription price which includes delivery by air where appropriate (but excluding VAT) of volume 20,2020, which includes print and electronic access, is f190 (US $\$ 313.00$ in USA, Canada and Mexico) for institutions. The electronic-only price available to

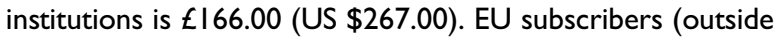
the UK) who are not registered for VAT should add VAT at their country's rate. VAT registered members should provide their VAT registration number. Japanese prices for institutions (including ASP delivery) are available from Kinokuniya Company Ltd, P.O. Box 55, Chitose, Tokyo I56, Japan.

Orders, which must be accompanied by payment, may be sent to a bookseller, subscription agent or direct to the publisher: Cambridge University Press, Journals Fulfillment Department. UPH, Shaftesbury Road. Cambridge CB2 8BS, UK; or in the USA, Canada and Mexico: Cambridge University Press, One Liberty Plaza, New York, NY 10006, USA. Periodicals postage paid at New York, NY and at additional mailing offices.

\section{Advertising}

To advertise in the journal please contact the relevant Advertising Promoter for your area: in the USA, Canada or Mexico: USAdSales@cambridge.org or telephone +| 212337
5053; in the UK, Europe or rest of the world: ad_sales@cambridge.org or telephone +44 1223325898.

\section{Copying}

This journal is registered with the Copyright Clearance Center, 222 Rosewood Drive, Danvers, MA 01923, USA. Organizations in the USA who are also registered with the C.C.C. may, therefore copy material (beyond the limits permitted by, sections 107 and 108 of U.S. Copyright law) subject to payment of the C.C.C. of the per copy fee of $\$ 10.50$. This consent does not extend to multiple copying for promotional or commercial purposes. Code 1472-6696/I3. ISI Tear Sheet Service, 350 I Market Street, Philadelphia, PA 19104, USA, is authorized to supply single copies of separate articles for private use only. Organizations authorized by the Copyright Licensing Agency may also copy material subject to the usual conditions. For all other use, permission should be sought from Cambridge or from the American Branch of Cambridge University Press.

Legal Information Management is included in the Cambridge Journals Online journals service which can be found at http://journals.cambridge.org. For further information on other Press journals access http://cambridge.org/journals.

Legal Information Management is indexed in Current Law Index, Legal Information Management Index, Legal Journals Index, Library Literature and Information Science. Legal Information Management also appears in full-text on Westlaw.

(C) British and Irish Association of Law Librarians and Contributors 2020 ISSN 1472-6696

\section{Cambridge University Press}

UPH, Shaftesbury Road, Cambridge CB2 8BS, UK

One Liberty Plaza, New York, NY 10006, USA

477 Williamstown Road, Port Melbourne, VIC 3207, Australia

Ruiz de Alaren 13, 28014, Madrid, Spain

Dock House, The Waterfront, Cape Town, 800I, South Africa

Printed in the United Kingdom by Bell \& Bain Ltd, Glasgow, UK 